\title{
Effects of micronutrients on placental function: evidence from clinical studies to animal models
}

\author{
Bernadette C Baker, Dexter JL Hayes and Rebecca L Jones \\ Maternal and Fetal Health Research Centre, Division of Developmental Biology and Medicine, School of Medical \\ Sciences, Faculty of Biology, Medicine and Health, University of Manchester, Manchester Academic Health Science \\ Centre, Manchester, UK
}

Correspondence should be addressed to R L Jones; Email: Rebecca.Lee.Jones@manchester.ac.uk

\begin{abstract}
Micronutrient deficiencies are common in pregnant women due to low dietary intake and increased requirements for fetal development. Low maternal micronutrient status is associated with a range of pregnancy pathologies involving placental dysfunction, including fetal growth restriction (FGR), small-for-gestational age (SGA), pre-eclampsia and preterm birth. However, clinical trials commonly fail to convincingly demonstrate beneficial effects of supplementation of individual micronutrients, attributed to heterogeneity and insufficient power, potential interactions and lack of mechanistic knowledge of effects on the placenta. We aimed to provide current evidence of relationships between selected micronutrients (vitamin D, vitamin A, iron, folate, vitamin B12) and adverse pregnancy outcomes, combined with understanding of actions on the placenta. Following a systematic literature search, we reviewed data from clinical, in vitro and in vivo studies of micronutrient deficiency and supplementation. Key findings are potential effects of micronutrient deficiencies on placental development and function, leading to impaired fetal growth. Studies in human trophoblast cells and rodent models provide insights into underpinning mechanisms. Interestingly, there is emerging evidence that deficiencies in all micronutrients examined induce a pro-inflammatory state in the placenta, drawing parallels with the inflammation detected in FGR, pre-eclampsia, stillbirth and preterm birth. Beneficial effects of supplementation are apparent in vitro and in animal models and for combined micronutrients in clinical studies. However, greater understanding of the roles of these micronutrients, and insight into their involvement in placental dysfunction, combined with more robust clinical studies, is needed to fully ascertain the potential benefits of supplementation in pregnancy.

Reproduction (2018) 156 R69-R82
\end{abstract}

\section{Introduction}

Adequate maternal nutritional status in pregnancy is important for fetal growth and development and for longterm health of the offspring. In high-income countries, macronutrient imbalances are relatively infrequent, however, deficiency in micronutrients (vitamins and minerals) are more common. In low- and middleincome countries micronutrient deficiencies are more common; a systematic review of micronutrient intake in women in developing countries found micronutrient intake, most commonly folate, to be below the estimated average requirement in over half of the included studies (Torheim et al. 2010). Micronutrient deficiencies are common in pregnant women due to insufficient dietary intake and increased requirements related to pregnancy (Darnton-Hill \& Mkparu 2015) Micronutrients are vital to the body's proper functioning and have extensive roles in cellular metabolism, proliferation, differentiation and signalling, and thus, inadequate levels can have wideranging effects. Normal development and function of the placenta is fundamental to a healthy, normally grown foetus and placental dysfunction is a major contributor to adverse pregnancy outcomes, particularly fetal growth restriction (FGR), small-for-gestational age infants (SGA), low birthweight (LBW), pre-eclampsia (PE) and stillbirth. Abnormalities in placental growth, cell survival, angiogenesis, vascular function and nutrient transport play key roles in the pathogenesis of these conditions (Worton et al. 2014). The placenta also mediates micronutrient partitioning between mother and foetus and thus is an important determinant of fetal micronutrient availability. The current review will focus on key micronutrients (iron, vitamin D, vitamin A, folate), selected based on their association with adverse outcomes related to placental dysfunction. We provide current understanding of their actions in the placenta following a systematic literature search strategy of clinical, in vivo and in vitro studies.

\section{Iron}

Iron is essential for the production of haemoglobin, cellular metabolism and immune system function. It is 
obtained in the diet as haem (meat, fish, eggs) or nonhaem forms (grains, pulses, nuts, fruit and vegetables), as well as fortified cereal products. Iron homeostasis is tightly regulated, with increased intestinal absorption and cellular uptake mediated by elevated divalent metal transporter 1 (DMT1) and transferrin receptor in deficient states (Fisher \& Nemeth 2017). Similar placental adaptive mechanisms exist that partially protect the foetus from maternal deficiency (Gambling et al. 2009, Cetin et al. 2011, Best et al. 2016). DMT1 uptake of transferrin-bound iron is the major route of placental iron uptake (McArdle et al. 2014), although additional mechanisms are implied by the viability of $D m t 1^{-}$ mouse foetuses (Gunshin et al. 2005, Cao \& O'Brien 2013). Iron depletion leads to iron-deficient anaemia (IDA), estimated to affect $15-20 \%$ of pregnant women worldwide (Gernand et al. 2016), with higher rates of up to $55 \%$ of pregnant women in low income countries (Casanueva \& Viteri 2003). IDA is associated with low birthweight (RR 1.29, 95\% Cl 1.09-1.53) and preterm birth (RR 1.21, 95\% Cl 1.13-1.30) (Haider et al. 2013), and cohort studies show an association with PE (Scholl 2005).

\section{Clinical studies}

A systematic review of randomised controlled trials (RCTs) of iron supplementation in pregnancy reported a positive dose-dependent effect on birth weight $(15.1 \mathrm{~g}$ for every $10 \mathrm{mg}$ increase in dose/day, $P=0.005)$ and a reduction in incidence of LBW (OR $0.81,95 \% \mathrm{CI}$ 0.71-0.93), with no significant influence on length of gestation (Haider et al. 2013). In this review, most trials were performed in iron-replete populations; subgroup analysis to examine neonatal outcomes according to anaemia status was not performed. Iron supplementation is recommended to pregnant women at risk of anaemia, generally from the second trimester to birth, continuing postpartum in populations where IDA is highly prevalent (Casanueva \& Viteri 2003). However, controversy exists regarding prophylactic iron supplementation in lowrisk populations due to potential adverse effects of iron overload, associated with increased oxidative stress and cellular toxicity (Friedrisch \& Friedrisch 2017) (see later section).

\section{Animal studies}

The effect of iron deficiency on pregnancy outcome has been tested in rat models, induced by dietary depletion. Whilst a consistent negative effect on fetal weight is reported, differences in outcome have been attributed to length of deficiency, with a reduction of litter size only apparent with extended deficiency (8 vs 0.5 weeks preconceptually) (Tojyo 1983, Sherman \& Moran 1984, Gambling et al. 2002, Toblli et al. 2012). Reduced placental weight occurs in severe models, whereas a compensatory increase in placental weight and labyrinth volume was observed with milder deficiency, leading to a distorted fetal:placental weight ratio (Lewis et al. 2001, Gambling et al. 2009). Impaired placental vascularisation has also been reported, which may impair maternal-fetal nutrient transfer (Lewis et al. 2001). In particular, these placental defects coupled with changes in placental lipid handling (including Fabp1) and maternal lipid metabolism, may contribute to the reduced fetal plasma amino acid and fatty acid concentrations apparent with maternal iron deficiency (Hay et al. 2016). Disrupted placental vascular development may also impact on feto-placental blood flow, as observed by increased umbilical artery resistance and pulsatility in a rat model of severe iron deficiency (Woodman et al. 2017). A systems biology approach involving whole embryo microarray and proteomic analysis identified key pathways affected by maternal iron deficiency. These included pathways regulating developmental processes, e.g. cytosketelal remodelling, cell adhesion and regulation of cell cycle. Validation studies focussed on potential gatekeepers of developmental programming; many of these are transcription factors (e.g. Sp1, C-myc, Tp53, Hnf4) and regulators of cell cycle checkpoints (Ccnb1 and proteasome complex components). Transcriptomic changes in regulatory genes were linked with increased expression of pro-apoptotic genes (Casp3 and Ppmd1), which may contribute to abnormal development of multiple organs and reduced expression of cytosketetal proteins actin and tubulin. Whether similar pathways and regulatory genes are altered in placentas remains unexplored (Swali et al. 2011).

As in other organs, anaemia induces oxidative stress and inflammation in rat placentas, with elevated proinflammatory Tnfa, Tnfr, $/ 16$ and Lep, and oxidative damage (lipid peroxidation) and reduced antioxidant status (Gambling et al. 2009, Toblli et al. 2012). Fetal hypoxia is also apparent, but variable evidence for placental hypoxia exists (Lewis et al. 2001, Toblli et al. 2012, Woodman et al. 2017). Placental oxidative stress and inflammation have detrimental effects on placental function in humans and rodents (Girard et al. 2014, Burton \& Jauniaux 2018), providing potential mechanistic insights into the association between IDA and reduced fetal growth and PE.

The effects of anaemia on adverse fetal outcomes and placenta can be recovered by iron supplementation, but only with IPC forms (iron(III)-hydroxide polymaltose complex with folic acid). IPC supplementation normalises anaemia-induced oxidative stress in the foetus and placenta and reduces IL6 and TNFA protein overexpression in the labyrinth region of the placenta (Toblli et al. 2012). In contrast, oral ferrous preparations that can by-pass physiological iron uptake mechanisms leading to elevated non-transferrin-bound iron, exacerbate inflammation and oxidative stress (Toblli 
et al. 2013). Free iron is highly reactive and can lead to free radical damage; this is seen in the intestinal mucosa, liver and placenta with excess iron supplementation, with corresponding increases in lipid peroxidation and mitochondrial dysfunction (Srigiridhar et al. 2001, Walter et al. 2002). There is some evidence that co-treatment of non-pregnant rats with antioxidants, e.g. vitamin $\mathrm{E}$ and $\mathrm{C}$, is protective against oxidative damage, suggesting more research is needed into multi-therapeutic approaches (Srigiridhar \& Nair 2000). An inflammatory environment can further affect iron homeostasis, providing evidence for a feedback loop to worsen cellular iron status (Ross 2017). This may be relevant to PE, where there is evidence for iron dysregulation and an established inflammatory pathogenic component (Kell \& Kenny 2016).

\section{In vitro studies}

There have been very few/no analyses of placentas from human pregnancies with maternal IDA. A study of ex vivo placental perfusion indicated potential beneficial effects of ferric carboxymaltose on placental capillary integrity and a reduction in apoptosis (Malek 2010). However, in vitro treatment of placental explants with iron $\left(\mathrm{FeCl}_{2}\right)$ augmented elevated trophoblast apoptosis in PE pregnancies (Shaker \& Sadik 2013). Further studies are needed to elucidate the relevance of animal studies on the human placenta, particularly the potential risk/ benefits of different iron formulations.

\section{Vitamin D}

Vitamin D is a fat-soluble hormone with widespread actions, including calcium homeostasis and bone metabolism, cellular proliferation, differentiation and immunomodulatory effects (Anderson et al. 2003). Vitamin D3 is synthesised in skin following exposure to sunlight and obtained through diet from oily fish, liver, egg yolks and some plants (in the form of vitamin D2). Infant formula milk, margarine and some breakfast cereals are fortified with vitamin D. Vitamin D is metabolised in the liver by cytochrome P450 27A1 (also known as CYP27A1) to $25(\mathrm{OH}) \mathrm{D}$, which is the major stable circulating form (bound to vitamin D-binding protein, DBP). Its actions are tightly regulated at the paracrine level, with local metabolism to the biologically active form $\left(1,25(\mathrm{OH})_{2} \mathrm{D}\right)$ by CYP27B1 and inactivation by CYP24A1. 1,25(OH $)_{2} \mathrm{D}$ acts via the vitamin $\mathrm{D}$ receptor, VDR, a member of the steroid hormone receptor family, which acts as a transcription factor in a heterodimer with retinoid X receptor (RXR) (Ryan et al. 2015).

There remain inconsistencies in the definition of vitamin $\mathrm{D}$ deficiency, ranging from serum concentrations of $25(\mathrm{OH}) \mathrm{D}$ of $25-75 \mathrm{nmol} / \mathrm{L}$, based solely on calcium homeostatic/skeletal actions. However, low vitamin $\mathrm{D}$ status is prevalent in pregnant women (reports vary between 20 and 60\%), with geographical, seasonal and ethnic influences (Looker et al. 2008, Bodnar \& Simhan 2010). A systematic review found significantly increased risk of PE (two-fold), gestational diabetes mellitus (GDM;1.4-fold), preterm birth (PTB;1.6-fold) and SGA (1.5-fold) with suboptimal vitamin D status (defined as $<50 \mathrm{nmol} / \mathrm{L})$ (Wei et al. 2013).

Fetal tissues highly express VDR, and there is evidence that fetal calcium levels and bone mineralisation are protected with maternal vitamin D deficiency (Kovacs et al. 2005). The placenta is also a target for vitamin D, with strong expression of VDR in syncytiotrophoblast and extravillous trophoblast (EVT). CYP27B1 is abundantly expressed by trophoblast and decidua, whilst CYP24A 1 is silenced, indicating high local bioactive vitamin $\mathrm{D}$ at the maternal-fetal interface (Evans et al. 2008). Reduced placental VDR expression and disrupted metabolism have been reported in pathological pregnancies, e.g. PE (Tamblyn et al. 2017), FGR (Nguyen et al. 2015) and recurrent miscarriage (Wang et al. 2016). Stimuli associated with placental dysfunction, such as oxidative stress and inflammation, can alter expression of VDR and CYP27B1, resulting in lower bioactive placental vitamin D (Shin et al. 2010, Barrera et al. 2015, Tamblyn et al. 2015).

\section{Clinical studies}

A 2017 systematic review and meta-analysis of vitamin D supplementation in pregnancy identified a modest beneficial effect on birthweight (mean increase of $58.33 \mathrm{~g}, 95 \% \mathrm{Cl} 18.88-97.78 \mathrm{~g}$ ) and a reduced risk of SGA (rRR 0.60, 95\% Cl 0.40-0.90) (Roth et al. 2017); in ten included trials, the mean baseline vitamin $\mathrm{D}$ status of participants was low (defined as $25(\mathrm{OH})$ $\mathrm{D}<30 \mathrm{nmol} / \mathrm{L}$ ), but these studies were not analysed separately. No protective effect against PE was detected, except in an analysis of three trials in which women were co-supplemented with vitamin D and calcium; these women had a reduced risk of PE (RR $0.51,95 \%$ Cl 0.32-0.80) (De-Regil et al. 2016). The review also found an increased risk of preterm birth (RR 1.57, 95\% Cl 1.02-2.43) in a subgroup analysis.

\section{Animal studies}

Female $V d r$-knockout mice have reduced fertility and litter sizes (Kovacs et al. 2005). Conflicting effects on fetal weights have been reported, with weights either lower (Kovacs et al. 2005) or unchanged from WT mice (Wilson et al. 2015). Calcium supplementation improved fertility, but had no impact on fetal outcomes. Furthermore, fetal mineral levels and skeletal mineralisation were normal in unsupplemented knockouts, consistent with evidence for adaptive increased placental calcium transport (Kovacs et al. 2005).

Dietary restriction in mice preconceptionally and during pregnancy altered the maternal renal 
renin-angiotensin system and elevated blood pressure (Liu et al. 2013). Placental morphological changes were also apparent, most notably a reduction in labyrinth vascularisation. Fetal weights were higher from vitamin D-deficient dams in late pregnancy, but this effect was reversed by 14 days postpartum, suggesting fetal and neonatal growth trajectories are altered. Vitamin D supplementation partially rescued both maternal and fetal phenotypes. A similar model identified a reduction in placental weight and vascularisation, accompanied by reduced expression of angiogenic Vegfa (Tesic et al. 2015). Placental expression of $11 \beta$-hydroxysteroid dehydrogenase-2 (11bhsd2) was also reduced, suggesting wider deleterious effects of deficiency through compromised protection from glucocorticoids.

Vitamin $\mathrm{D}$ has known anti-inflammatory and immunomodulatory actions in other organs, and this has been reinforced by placental studies. Treatment of mice with the inflammatory stimulus LPS induces placental $V d r$ and Cyp27b1 mRNA, indicating an endogenous anti-inflammatory response (Liu et al. 2011). Knockout of $V d r$ or Cyp27b1 resulted in a pro-inflammatory bias in placentas and heightened responses to LPS challenge ex vivo, with elevated expression of T/r2 and proinflammatory cytokines (including Ifng, Tnfa and I/6) and chemokines (including $\mathrm{CCl} 2, \mathrm{CxCl} 10, \mathrm{Cxcl6}$ ) (Liu et al. 2011, 2017). Interestingly, a more severe phenotype was observed in placentas from female pups, indicating a degree of sexual dimorphism. Ex vivo treatment of WT placentas with vitamin D had anti-inflammatory effects, reducing cytokine and chemokine expression.

A central role for vitamin D in regulating placental inflammatory pathways was reinforced in a mouse model of LPS-induced FGR and fetal death (Chen et al. 2015a). In this model, LPS treatment did not affect VDR expression, but prevented its activation and target gene expression. Pre-treatment of mice with vitamin D effectively rescued fetal and placental growth and increased fetal viability. This was associated with attenuated LPS-induced pro-inflammatory cytokine (Tnfa, $/ / 1 b$ and $/ / 6$ ) and chemokine (Ccl2, Cxcl1, Cxcl2) levels in both maternal and placental compartments. These anti-inflammatory effects were attributed to a blockade of NFkB activation by vitamin $\mathrm{D}$. This represents a distinct mechanistic pathway to that in immune cells, whereby vitamin D exerts anti-inflammatory effects via PI3K/Akt signalling pathways. LPS treatment also reduced placental folate transporters in mice, with a concordant rise in incidence of neural tube defects in offspring (Chen et al. 2015b). Supplementation with vitamin $D$ rescued folate transport and prevented neural tube defects, signifying a link between the anti-inflammatory effects of vitamin D and folate biology (see later section). Additional mechanistic pathways altered by vitamin $\mathrm{D}$ in mouse placenta have been identified by gene array studies, including those regulating autophagy, cell signalling and the mTOR pathway (Wilson et al. 2015).
The therapeutic potential of vitamin D was also been explored in a rat model of placental ischaemia, induced by ligation of the uterine artery (Tian et al. 2016). Vitamin $\mathrm{D}$ prevented preeclamptic-type symptoms in pregnant dams, reduced fetal mortality and prevented effects of ischaemia on placental morphology and cell survival, associated with a decrease in placental oxidative and endoplasmic reticulum stress. In vitro analyses indicated normalisation of placental sFLT1 release as a primary mechanism underpinning the prevention of maternal endothelial activation (Ma et al. 2017).

Studies in the 1960s and 70s raised concerns about excessive antenatal supplementation with vitamin D2. High-dose supplementation (up to 40,000 IU/day) in pregnant rats resulted in reduced placental size, coupled with histological features of abnormal placental development (including delayed trophoblast differentiation and vascularisation), placental calcification and inflammation (Potvliege 1962). Extended supplementation in late pregnancy had additional adverse fetal effects, with reduced fetal weights and high rates of fetal loss at term (Ornoy et al. 1968, Nebel \& Ornoy 1971, 1972). There is no current evidence for similar effects in humans; however, vitamin D3 is more effective at raising serum vitamin $\mathrm{D}$ concentrations and thus is now the favoured form (Houghton \& Vieth 2006).

\section{In vitro studies}

In vitro studies of human placental cell lines and primary trophoblasts have confirmed and extended our understanding of potential roles for vitamin $D$ in the placenta. As in the mouse, vitamin $D$ exerts antiinflammatory effects via VDR in JEG3 cells, attenuating LPS-induced nuclear translocation of NFkB p65 subunit and pro-inflammatory cytokine expression (IL6 and TNFA) (Chen et al. 2015a). Similarly, vitamin $\mathrm{D}$ acting through VDR dose dependently abolishes pro-inflammatory effects of TNFA in trophoblast cells, preventing the expression of IL6, IFNG and TNFA itself (Noyola-Martinez et al. 2013). These effects may be relevant to PE; all three cytokines are expressed at higher levels by placental cells from preeclamptic women and are decreased by vitamin $\mathrm{D}$ treatment in vitro. Antiinflammatory effects of vitamin D were also observed in an in vitro model of anti-phospholipid syndrome (APS) - another immunological pregnancy disorder including suppression of IL1B and IL8, together with reduced microparticle release (Barrera et al. 2015, Gysler et al. 2015). Vitamin D has also been reported to have antimicrobial effects by stimulating the expression of $\beta$-defensins and cathelicidin in trophoblast cells (Olmos-Ortiz et al. 2015).

Vitamin D may be beneficial during the establishment of pregnancy, by promoting an immunologically tolerant environment in the decidua and regulating a 
number of genes critical for implantation, e.g. CABP9K and HOXA10 (reviewed elsewhere Evans et al. 2004, Ganguly et al. 2018). Vitamin D also promotes EVT invasion in vitro (Chan et al. 2015) and can modulate the inhibitory effects of locally active lipid metabolite sphingosine-1-phosphate (S1P) on EVT migration (Hay et al. 2016). These findings provide insight into the biological significance of high local vitamin D levels in the decidua and the increased susceptibility of vitamin D-deficient women to PE, where early placentation is defective. Further potential actions in PE include effects on maternal endothelial cells, as noted in rodent studies, including negative regulation of antiangiogenic sFLT-1, stimulation of VEGF and e-NOS, and enhanced antioxidant defences (reviewed in detail in Barrera et al. 2015).

Vitamin D can influence cell proliferation and survival and in trophoblast cells regulate cell cycle regulatory genes (TP53, cyclin-dependent kinase inhibitors), inhibits pro-apoptotic caspase 3 and alters expression of growth factors, including TGFB, important for trophoblast proliferation and differentiation (Nguyen et al. 2015, Xu et al. 2017). In addition to regulating placental calcium transport (Tuan 1991), vitamin D may enhance general fetal nutrient availability, e.g. a positive association has been reported between maternal vitamin $\mathrm{D}$ status and placental amino acid transport via system A (Cleal et al. 2015). Vitamin D can also stimulate placental hCG, hPL and steroidogenesis and thus could have profound effects on maternal metabolism and pregnancy maintenance (Stephanou et al. 1994, Barrera et al. 2007, 2008). Low maternal vitamin D status may therefore predispose to FGR and PE via multiple actions on maternal and placental physiology.

\section{Vitamin A}

Vitamin A consists of a group of naturally occurring fatsoluble compounds obtained from the diet. Retinol and retinyl esters are present in animal sources and betacarotene or other provitamin A carotenoids in plants, with the total vitamin A content of the diet expressed as retinol activity equivalents (RAEs). Biologically active forms of vitamin A (retinol, retinal and retinoic acid) have essential roles in normal vision, immune function, cell differentiation and reproduction, with actions exerted through nuclear receptors (RAR $\alpha, \beta$ and $\gamma$ ) which, like VDR, heterodimerise with RXR and alter gene transcription. Recent reviews describe vitamin A uptake, transport and storage in general (Chelstowska et al. 2016) and by the placenta (Spiegler et al. 2012).

Vitamin A deficiency is assessed by biochemical measurement of serum retinol, clinical indication of eye disease and functional indicators such as night blindness. Adult serum retinol concentrations $<0.7 \mu \mathrm{mol} / \mathrm{L}$ define biochemical deficiency and in pregnancy/lactation concentrations $<1.05 \mu \mathrm{mol} / \mathrm{L}$ are considered deficient
(Wiseman et al. 2017). Vitamin A deficiency is common in low-income countries, with $\sim 15 \%$ of pregnant women globally being biochemically deficient (World Health Organization 2009). However, even in the United Kingdom and United States particular subpopulations are at risk of deficiency, including adolescent girls, African-Americans and those in low socioeconomic groups (Hanson et al. 2016). Vitamin A deficiency is associated with increased incidence of preterm birth (OR 1.99, 95\% Cl 1.12-3.53) (Radhika et al. 2002). However, current guidance is to avoid excessive vitamin A intake in pregnancy from supplement and dietary forms (no more than $800 \mu \mathrm{g}$ RAE/day) (FAO/WHO 2005) due to potential teratogenic effects. Supplementation is only recommended for populations where vitamin $A$ deficiency is a severe public health problem.

\section{Clinical studies}

A recent Cochrane review evaluating RCTs of vitamin A supplementation in areas endemic for deficiency (17 of 19 included studies were conducted in populations considered to be deficient) found a decreased risk of maternal night blindness (ocular sign of vitamin A deficiency), anaemia and clinical infection in women, but no beneficial effect on fetal/neonatal outcomes (McCauley et al. 2015). Vitamin A has potent immune regulatory effects and can alter the balance between Th1/Th2 responses, with a tendency to suppress proinflammatory responses (Villamor \& Fawzi 2005). Pregnancy is associated with altered immune responses; a bias towards Th2 responses by vitamin A would be hypothesised to be favourable to pregnancy outcomes; however, concerns regarding susceptibility to maternal and fetal infection warrant further investigation, particularly given the prevalence of vitamin A deficiency in populations at high risk of malaria and HIV infection (Cox et al. 2006, Cañete et al. 2017).

\section{Animal studies}

The role of vitamin A on placental and fetal development has been addressed in animal models of deficiency and excess, delineating different roles for retinoic acid and retinol during pregnancy. A total vitamin A-deficient diet results in extensive embryonic resorption by midpregnancy in rats (Takahashi et al. 1975); this can be rescued by supplementation with retinol, but not retinoic acid, demonstrating a non-redundant role in embryonic development (Wellik \& DeLuca 1995). Supplementation of vitamin A-deficient rats with all-trans-retinoic acid (the highest affinity ligand for RAR) supports survival of offspring to parturition (White et al. 1998).

More moderate models of deficiency have identified effects on the placenta. Restricted dietary intake of retinyl acetate (acetylated form of retinol) led to decreased litter size and pup viability. Fetal growth 
rates were impaired and defects in placental growth and histological appearance were detected from midpregnancy (Takahashi et al. 1975). A similar phenotype was observed in rats fed a retinol-free diet 8 weeks before and throughout pregnancy, with lower numbers of viable foetuses, and increased placental weight and placental/ fetal weight ratio for surviving pups (Antipatis et al. 2002). Placentas had increased neutrophil infiltration and higher LEPTIN, TNFA and TNFR expression, together with increased apoptosis and altered BCL2/BAX ratio in adjacent trophoblast cells.

Mice with mutations in more than one of the Rar or $R x r$ subtype exhibit many of the same embryonic defects as dams maintained on marginal vitamin A intakes (reviewed in Mark et al. 2009). Of note, embryonic death in Rxra- and Rxrb-null mice is attributed to defective development of the placental labyrinthine zone (Wendling et al. 1999).

Hypervitaminosis A results in congenital malformations, due to wide-ranging developmental actions, including axial polarisation and cell morphogenesis (Clagett-Dame \& Knutson 2011). A single dose of retinoic acid equivalent to $240 \mathrm{mg} / \mathrm{kg}$ $(800,000 \mathrm{IU} / \mathrm{kg})$ in early rat pregnancy resulted in almost all embryos dying with cardiovascular and nervous system defects and hydraemia $24 \mathrm{~h}$ after treatment (Love \& Vickers 1976). There was suppression of allantois leading to placental agenesis. A lower single dose of all-trans-retinoic acid $(120 \mathrm{mg} / \mathrm{kg})$ on gestational day 10 induced a clubfoot-like deformity and altered placental morphology, with increased apoptosis and altered BCL2:BAX ratio (Jiang et al. 2014). No effects on placental or fetal weight were observed.

\section{In vitro studies}

In both human and rat trophoblast cells, vitamin A regulates secretion of hormones important for trophoblast differentiation, fetal nutrient availability and maternal energy expenditure. Retinoic acid increases secretion of hCG by human choriocarcinoma cells in a dosedependent manner, with similar effects on progesterone although this varied between cell lines (Chou 1982, Kato \& Braunstein 1991). Similar experiments with rat primary differentiated spongiotrophoblast cells demonstrated effects on morphology with more welldefined nuclei and thinner and fewer cytoplasmic projections in retinoic acid treated cells and reduced placental prolactin levels (Lu et al. 1994). The production of hormone leptin is also stimulated by retinoic acid in primary human trophoblasts mediated by the RXR $\alpha$ receptor (Guibourdenche et al. 2000). This receptor also mediates transcription of pregnancy-specific glycoprotein 5 (PSG5) in JEG-3 cells in response to retinoic acid (Lopez-Diaz et al. 2007). PSGs are thought to be important in mediating fetal protection from the maternal immune system and reduced PSG secretion in vitamin A-deficient animal models may partly explain the observed placental inflammatory responses.

Further effects on placental development and function have been suggested from in vitro analyses of human placentas. Antagonism of RXR stimulated invasion of primary human EVTs through ECM-coated transwells (Tarrade et al. 2001). Ex vivo human placental perfusion studies identified beneficial effects of beta-carotene on placental vascular tone, with an attenuation of peroxideinduced vasoconstriction and reduced lipid peroxide and TXB2 production (Cueto et al. 1997).

\section{Folate and vitamin B12}

Folate and vitamin B12 (cobalamin) are naturally occurring, water-soluble vitamins present in biological tissues and foodstuffs. Both play critical roles in onecarbon metabolism, which generate purines and thymidylate for DNA synthesis/repair and S-adenosylmethionine (SAM), the donor for cellular methylation reactions and remethylates cytotoxic homocysteine to methionine (Molloy 2012). Folate deficiency is characterised by elevated homocysteine and clinically manifests as megaloblastic anaemia. Recently, evidence for a critical role of folate in protection against oxidative stress, via generation of NADPH has emerged (Fan et al. 2014). Vitamin B12 is also essential for myelinogenesis and red blood cell production, thus deficiency leads to neurological damage and anaemia.

Absorption, transport and intracellular storage of folate in non-pregnant adults is tightly controlled and both folate and vitamin B12 are present at higher concentrations in fetal than maternal circulation (Suh et al. 2001). Vitamin B12 is predominantly transported across the placenta by transcobalamin (Fisher \& Nemeth 2017), and recent studies propose transplacental folate transport via folate receptor $\alpha(F R \alpha)$, proton-coupled folate transporter (PCFT) and reduced folate carrier (RFC) (Solanky et al. 2010, Rosario et al. 2017a). Folate requirements are increased in pregnancy to meet the needs of the developing foetus and thus pregnant women are at risk of folate deficiency. Low maternal folate status is associated with neural tube defects and other congenital abnormalities (de Benoist 2008), with evidence from observational studies for associations with PE, FGR/ SGA and preterm birth (Ek 1982, Scholl \& Johnson 2000, Rao et al. 2001, Baker et al. 2009, Bukowski et al. 2009). Current guidance for folic acid supplementation by healthy women is $400-800 \mu \mathrm{g} /$ day preconceptually and throughout the first trimester. As many pregnancies are unplanned, many countries recommend daily supplementation by all women of reproductive age. However, supplementation rates are low in many groups of women in the United Kingdom and the United States (e.g. adolescents), and higher rates of deficiency (up to $26 \%$ of pregnant women) are reported in low-income countries (Gernand et al. 2016). Folate deficiency is 
currently defined as serum folate $<10 \mathrm{nmol} / \mathrm{L}$ and red blood cell folate $<340 \mathrm{nmol} / \mathrm{L}$, based on the increased plasma homocysteine; however, recent guidance suggests RBC folate concentrations $>906 \mathrm{nmol} / \mathrm{L}$ are required to achieve the greatest reduction in neural tube defects occurrence (Cordero et al. 2015). A growing proportion of pregnant women at higher risk of neural tube defects are recommended to supplement with highdose folic acid (4-5 mg/day), far exceeding the tolerable upper limit of $1 \mathrm{mg} /$ day for a non-pregnant adult.

Vitamin B12 deficiency (serum concentrations $<150 \mathrm{pmol} / \mathrm{L}$ ) is common in countries where a vegan diet is consumed. A recent systematic review estimated a worldwide prevalence of 19-29\% (Sukumar et al. 2016); however, deficiency rates in UK and USA are low. In the UK, recommended intake of vitamin B12 in pregnancy is $2.6 \mu \mathrm{g} /$ day. In addition to increased risk of neural tube defects, maternal B12 deficiency is associated with both increased risk of LBW (RR 1.15, 95\% Cl 1.01-1.31) and preterm birth (RR 1.21, 95\% Cl 0.99-1.49) (Rogne et al. 2017).

\section{Clinical trials}

Folic acid supplementation is effective in reducing neural tube defects (De-Regil et al. 2015). A recent metaanalysis detected a positive influence of maternal RBC folate concentrations on birthweight and risk of SGA (van Uitert \& Steegers-Theunissen 2012). This was reinforced by a systematic review of folic acid supplementation RCTs finding an increase in birthweight (mean $135.75 \mathrm{~g}$, 95\% Cl 47.85-223.68) with folic acid supplementation, but no effects on other pregnancy outcomes. It is noteworthy that many of these trials tested folic acid in combination with iron supplementation, with a range of comparator control groups and found no overall beneficial effect of supplementation on maternal folate status (Lassi et al. 2013). Both these reviews included studies of mostly replete populations, and in some cases, these studies excluded women with low folate and/or iron levels. A more focussed analysis of folic acid vs placebo also found a small but significant increase in birthweight $(2 \%$ increase, $P<0.0001)$ with a twofold increase in folate intake (Fekete et al. 2012). The timing of supplementation may have an impact with two recent analyses suggesting the protection against SGA is dependent on pre-conceptual supplementation (Hodgetts et al. 2014). Supplementing with folic acid may have adverse effects in individuals with low vitamin B12 status and has been associated with increased incidence of SGA birth (Dwarkanath et al. 2013). Vitamin B12 supplementation during pregnancy has been evaluated in a single RCT to date (Duggan et al. 2014), reporting a beneficial effect on maternal and infant plasma B12 concentrations, but with no difference in incidence of SGA.

\section{Animal studies}

The importance of folate in embryonic development was first realised in animal studies in the 1950s in which rats fed a folate-deficient diet during pregnancy produced offspring with multiple congenital anomalies (Nelson et al. 1952). More recent rodent studies have identified effects of folate deficiency on one carbon metabolism in the foetus, placenta and mother. These include a reduced S-adenosylmethionine:Sadenosylhomocysteine (SAM:SAH) ratio indicative of lower production of methyl donors, accompanied by a global decrease in placental DNA methylation (Kim et al. 2009) and altered expression of specific genes predicted to disrupt numerous metabolic pathways (McKay \& Mathers 2016). A similar reduction in SAM:SAH ratio was measured in maternal plasma and liver of folate-deficient mice. This was associated with hyper-homocystenaemia and inflammation, with elevated expression of placental Ifng (Mikael et al. 2013). Mice fed a folate-deficient diet had decreased fetal weights, with unaltered placental weight, litter size and crown rump length (Rosario et al. 2017 b). Folate deficiency led to inhibition of placental mTORC signalling and decreased amino acid transporter expression and activity.

The effects of a number of polymorphisms in one carbon cycle enzymes (MTHFR and MTHFD) that occur in the human population have been investigated in mice, as they may modulate the outcomes of excess or deficient folate supply in pregnancy. Folate-deficient mice or Mthfr heterozygotes (a model for the prevalent 677TT polymorphism) suffered higher rates of embryonic loss, congenital abnormalities, developmental delay and FGR (Pickell et al. 2009). Decreased placental weight and area was also observed in folate-deficient mice with equal decreases in both the junctional and labyrinth zones. A mouse model for the human R653Q variant (Mthfd1s+/-) fed a five-fold higher folic acid diet before and during pregnancy also showed increased embryonic and placental defects at E10.5, particularly in the labyrinth zone (Christensen et al. 2016). In both studies, the combination of dietary deficiency and genotype exacerbated the defects.

Other studies in animal models indicate adverse effect of high levels of folic acid supplementation on fetal growth. Rats supplemented with $40 \mathrm{mg} / \mathrm{kg}$ vs $2 \mathrm{mg} / \mathrm{kg}$ throughout pregnancy had offspring with significantly reduced birthweight and crown rump length (Achon et al. 2000). Similarly, embryos from mice fed a high folic acid diet had showed embryonic delay and growth retardation and heart defects in earlyto-mid pregnancy (Pickell et al. 2011). Excess folic acid administered to pregnant rats $(8 \mathrm{mg} / \mathrm{kg}$ vs $1 \mathrm{mg} /$ $\mathrm{kg}$ ) resulted in sexually dimorphic responses, with reduced $11 \beta-\mathrm{HSD} 2$ expression (related to promoter hypermethylation) in male placentas from male infants only (Penailillo et al. 2015). No alteration was detected 
in female pups, who instead had increased birthweights. This suggests over supply, as well as deficiency of folic acid, can affect offspring responses and programme for future health. Finding equivalent evidence in humans is difficult, but two studies found a strong association with higher folic acid supplementation in pregnancy and impaired respiratory health in children (Haberg et al. 2009, Whitrow et al. 2009). This effect of high methyl donor supplementation during pregnancy on allergic airway disease in offspring has also been observed in mice (Hollingsworth et al. 2008).

The negative effects of vitamin B12 deficiency alone, and in the presence of excess folic acid supplementation, on placental and fetal development has been examined in several animal studies. Maternal vitamin B12 deficiency in rats altered placental phospholipid ratios, particularly phosphatidylcholine and phosphoethanolamine (Khot et al. 2014) and decreased placental expression of $\Delta 5$ desaturase and fatty acid transporters Fatp 1 and 4 (Wadhwani et al. 2013). Excess FA (8 mg/kg vs $2 \mathrm{mg} /$ $\mathrm{kg}$ ) combined with B12 deficiency decreased global placental DNA methylation in rats (Kulkarni et al. 2011) and altered expression of one carbon metabolism enzymes including Mthfr and methionine synthase (Khot et al. 2014). In contrast, vitamin B12 attenuated the negative effects of high folic acid ( $5 \mathrm{mg} /$ day vs $400 \mu \mathrm{g}$ ) on birth and placental weight in rats (Shah et al. 2017).
Some of the placental effects may relate to modulation of placental microRNAs, with high folate decreasing, and vitamin B12 increasing, miR-16 and miR-21 expression.

\section{In vitro studies}

In vitro studies provide evidence of adverse effects of folate deficiency on placental function. Culture in low folate conditions increased apoptosis in primary trophoblasts from human term placentas (Steegers-Theunissen et al. 2000), and reduced viability, proliferation and invasive capacity in JEG-3 (Moussa et al. 2015) and HTR-8/ SVneo (Ahmed et al. 2016) cell lines. Homocysteine treatment increased trophoblast apoptosis and reduced hCG secretion (Di Simone et al. 2004). These negative effects on trophoblast survival and function were reversed by addition of folic acid in a dose-dependent manner, and folic acid treatment alone increased hCG production. Metabolic effects have also been reported with inhibition of mTOR signalling and reduced amino acid transport via system $A$ and system $L$ in primary human cytotrophoblasts cultured in folate-deficient media (Rosario et al. 2017a) concordant with evidence in mice (Rosario et al. 2017b).

In vitro studies also provide supportive evidence for detrimental effects of excess folic acid on the placenta, with a reduction in BeWo and JEG3 cell viability

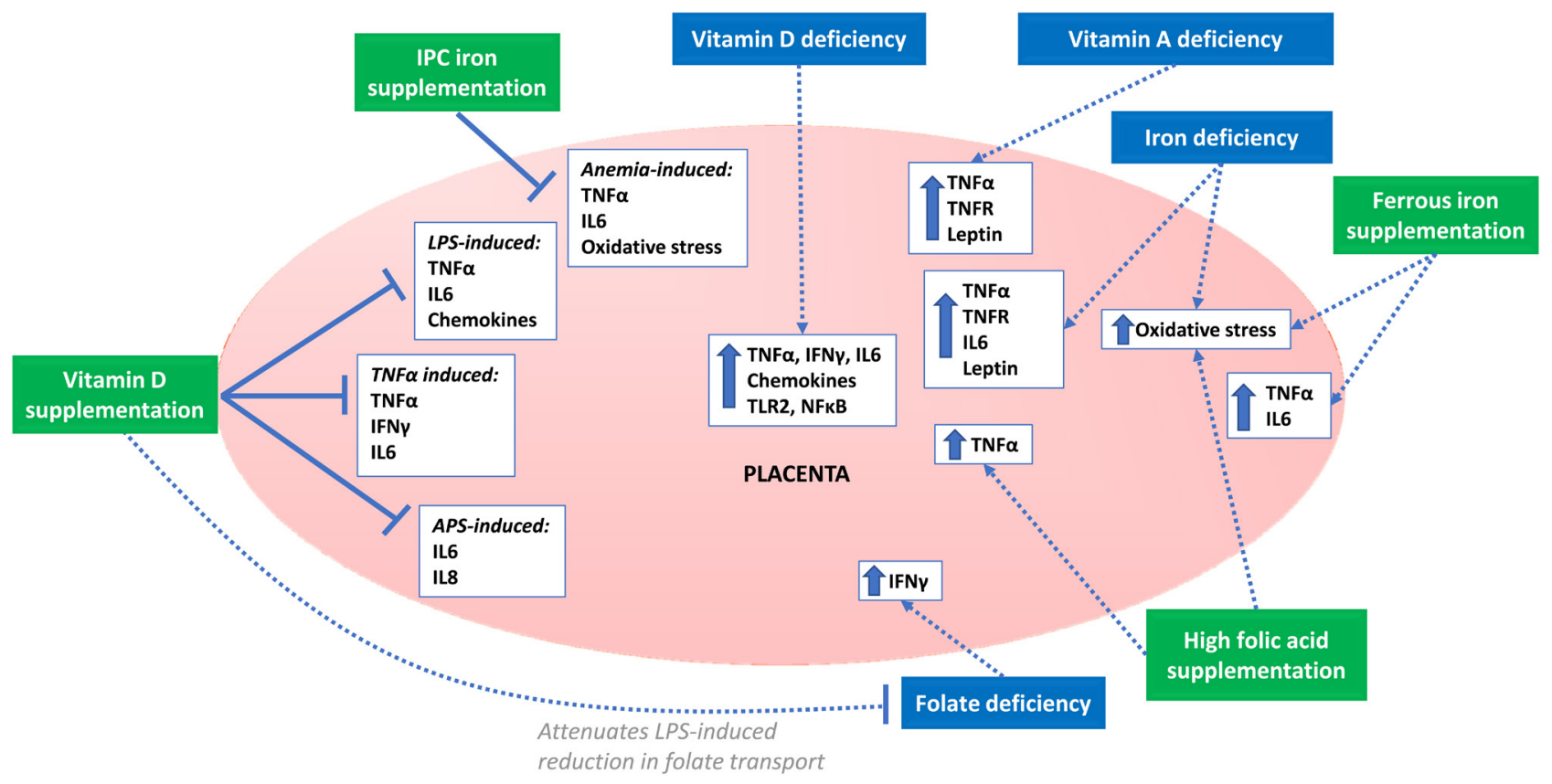

Figure 1 Effects of micronutrient deficiency and supplementation on placental inflammation. Data from rodent and human pregnancies indicate pro-inflammatory effects of maternal deficiency of vitamin D, vitamin A, iron and folate on the placenta, with a prominent involvement of cytokines, especially tumour necrosis factor (TNF)A, interleukin (IL)- 6 and interferon (IFN)G. Similar effects have been described in response to supplementation with high-dose folic acid, together with increased oxidative stress. Vitamin D supplementation can attenuate pro-inflammatory effects of inflammatory stimuli, including lipopolysaccharide (LPS), TNFA and anti-phospholipid antibodies (APS), whilst the form of iron supplementation (ferrous vs IPC (iron(III)-hydroxide polymaltose complex with folic acid)) determines whether there are beneficial or detrimental effects on anaemia-induced inflammation and oxidative stress. 
(Ahmed et al. 2016, Shah et al. 2016). This was associated with decreased EGF receptor expression, and elevated TNFA mRNA, homocysteine and lipid peroxidation marker malondialdehyde (MDA). Supplementation with vitamin B12 restored cell viability and significantly reduced both homocysteine and MDA levels.

\section{Conclusion}

Micronutrient deficiencies are prevalent in pregnant women and have been linked to a range of adverse pregnancy outcomes. Despite this RCTs of supplementation studies of individual micronutrients have frequently failed to show consistent improvements in most fetal outcomes, with common issues of insufficient statistical power, poor quality and substantial heterogeneity identified by systematic reviews. A major source of heterogeneity is the baseline characteristics of the study populations; all the systematic reviews include studies of pregnant women who are deficient and replete in the micronutrient of interest, with very few performing sub-analyses of deficient participants alone. In addition, many of the studies include participants with co-morbidities, both obstetric or pre-existing, introducing further confounding effects that complicate the analysis of individual micronutrient effects on pregnancy outcome.

However, strong evidence for the beneficial effects of micronutrients on fetal/neonatal outcomes comes from a systematic review of multi-micronutrient $(\mathrm{MMN})$ supplementation, showing a reduction in the incidence of LBW (RR $0.88(0.85-0.91)$ ) and SGA (RR 0.92 (0.86-0.98)) (Haider et al. 2013), leading to a recommendation for MMN to replace supplementation with individual micronutrients (most commonly iron and folate) in pregnant women at high risk of deficiencies. The beneficial effects of MMN are probably due to interactions between micronutrients and the fact that single micronutrient deficiencies are rarely seen in isolation (Haider et al. 2013). Several interactions have been described in this review, including between folate and other micronutrients, but also there are other established interactions between vitamin A, iron and zinc that impact on bioavailability of these nutrients.

Notwithstanding the issues with clinical studies, mechanistic studies have identified significant effects of micronutrient deficiency on the placenta and have begun to decipher mechanistic pathways affected by micronutrients. In vivo animal models provide the opportunity to dissect the effects of stark maternal deficiency on pregnancy outcome in a whole body system, enabling analysis of effects on fetal growth and survival. These models are more extreme than the clinical scenario and enable manipulation of single micronutrients through dietary depletion or gene knockout of key signalling components, whilst controlling for confounding factors. These are useful to identifying mechanistic pathways of action, but need careful interpretation given the previously mentioned co-existence of micronutrient deficiency, common signalling pathways (e.g. vitamin A and D, B vitamins) and the inherent limitations in comparisons of rodent and human pregnancies (including differences in placental structure, fetal number and length of pregnancy) (Bonney 2013). However, coupled with in vitro analyses of human placentas, these studies enable construction of hypotheses to be tested in clinical studies.

The micronutrients discussed have wide-ranging actions, and these are reflected in diverse effects on the placenta. However, an emerging common theme is their effects on placental inflammation (Fig. 1), which is relevant to numerous pregnancy pathologies, including FGR, PE and stillbirth (Nadeau-Vallee et al. 2016). All four micronutrients studied in this review have immunomodulatory effects, and in vitro/in vivo models of deficiency have demonstrated pro-inflammatory effects in the placenta including upregulation of pro-inflammatory cytokines (Antipatis et al. 2002, Gambling et al. 2009, Liu et al. 2011, 2017, Toblli et al. 2012, Mikael et al. 2013). Interestingly, vitamin D supplementation can have anti-inflammatory effects on placental inflammation induced by other stimuli, such as LPS, TNFA or auto-antibodies (NoyolaMartinez et al. 2013, Barrera et al. 2015, Chen et al. 2015b, Gysler et al. 2015), suggesting therapeutic uses in non-deficient women. Whether vitamin A has similar effects on placental inflammation has not been studied, but the commonalities in signalling pathways via RXR warrant further investigation. Iron supplementation can overcome the inflammatory effects of anaemia, but this is dependent on the form used (Toblli et al. 2012, 2013), with ferrous forms exacerbating inflammation and oxidative stress in rat models. Further research is needed to fully elucidate the immunomodulatory and other actions of micronutrients on the placenta, and their contribution to placental dysfunction and pregnancy pathologies. More robust and adequately powered clinical studies will enable translation of knowledge from animal and in vitro experimental studies and better targeting to obstetric populations most likely to benefit from individual micronutrient supplementation.

\section{Declaration of interest}

The authors declare that there is no conflict of interest that could be perceived as prejudicing the impartiality of this review.

\section{Funding}

This research did not receive any specific grant from any funding agency in the public, commercial or not-for-profit sector. 


\section{Acknowledgements}

The authors acknowledge the assistance of Dr Samantha Lean in the literature searching and abstract screening.

\section{References}

Achon M, Alonso-Aperte E, Reyes L, Ubeda N \& Varela-Moreiras G 2000 High-dose folic acid supplementation in rats: effects on gestation and the methionine cycle. British Journal of Nutrition 83 177-183. (https://doi. org/10.1017/S0007114500000222)

Ahmed T, Fellus I, Gaudet J, MacFarlane AJ, Fontaine-Bisson B \& Bainbridge SA 2016 Effect of folic acid on human trophoblast health and function in vitro. Placenta 37 7-15. (https://doi.org/10.1016/j. placenta.2015.11.012)

Anderson PH, May BK \& Morris HA 2003 Vitamin D metabolism: new concepts and clinical implications. Clinical Biochemist Reviews 24 $13-26$.

Antipatis C, Ashworth CJ, Riley SC, Hannah L, Hoggard N \& Lea RG 2002 Vitamin A deficiency during rat pregnancy alters placental TNF- $\alpha$ signalling and apoptosis. American Journal of Reproductive Immunology 47 151-158. (https://doi.org/10.1034/j.1600-0897.2002.1o049.x)

Baker PN, Wheeler SJ, Sanders TA, Thomas JE, Hutchinson CJ, Clarke K, Berry JL, Jones RL, Seed PT \& Poston L 2009 A prospective study of micronutrient status in adolescent pregnancy. American Journal of Clinical Nutrition 89 1114-1124. (https://doi.org/10.3945/ajcn.2008.27097)

Barrera D, Avila E, Hernández G, Halhali A, Biruete B, Larrea F \& Díaz L 2007 Estradiol and progesterone synthesis in human placenta is stimulated by calcitriol. Journal of Steroid Biochemistry and Molecular Biology 103 529-532. (https://doi.org/10.1016/j.jsbmb.2006.12.097)

Barrera D, Avila E, Hernández G, Méndez I, González L, Halhali A, Larrea F, Morales A \& Díaz L 2008 Calcitriol affects hCG gene transcription in cultured human syncytiotrophoblasts. Reproductive Biology and Endocrinology 6 3. (https://doi.org/10.1186/1477-7827-6-3)

Barrera D, Díaz L, Noyola-Martínez N \& Halhali A 2015 Vitamin D and inflammatory cytokines in healthy and preeclamptic pregnancies. Nutrients 7 6465-6490. (https://doi.org/10.3390/nu7085293)

Best CM, Pressman EK, Cao C, Cooper E, Guillet R, Yost OL, Galati J, Kent TR \& O'Brien KO 2016 Maternal iron status during pregnancy compared with neonatal iron status better predicts placental iron transporter expression in humans. FASEB Journal 30 3541-3550. (https:// doi.org/10.1096/fj.201600069R)

Bodnar LM \& Simhan HN 2010 Vitamin D may be a link to black-white disparities in adverse birth outcomes. Obstetrical and Gynecological Survey 65 273. (https://doi.org/10.1097/OGX.0b013e3181dbc55b)

Bonney EA 2013 Demystifying animal models of adverse pregnancy outcomes: touching bench and bedside. American Journal of Reproductive Immunology 69 567-584. (https://doi.org/10.1111/ aji.12102)

Bukowski R, Malone FD, Porter FT, Nyberg DA, Comstock $\mathrm{CH}$, Hankins GD, Eddleman K, Gross SJ, Dugoff L \& Craigo SD 2009 Preconceptional folate supplementation and the risk of spontaneous preterm birth: a cohort study. PLoS Medicine 6 e1000061. (https://doi. org/10.1371/journal.pmed.1000061)

Burton GJ \& Jauniaux E 2018 Pathophysiology of placental-derived fetal growth restriction. American Journal of Obstetrics and Gynecology 218 S745-S761. (https://doi.org/10.1016/j.ajog.2017.11.577)

Cañete A, Cano E, Muñoz-Chápuli R \& Carmona R 2017 Role of vitamin $\mathrm{A} /$ retinoic acid in regulation of embryonic and adult hematopoiesis. Nutrients 9 159. (https://doi.org/10.3390/nu9020159)

Cao C \& O'Brien KO 2013 Pregnancy and iron homeostasis: an update. Nutrition Reviews 71 35-51. (https://doi.org/10.1111/j.17534887.2012.00550.x)

Casanueva E \& Viteri FE 2003 Iron and oxidative stress in pregnancy. Journal of Nutrition 133 1700S-1708S. (https://doi.org/10.1093/jn/133.5.1700S)

Cetin I, Berti C, Mandò C \& Parisi F 2011 Placental iron transport and maternal absorption. Annals of Nutrition and Metabolism 59 55-58. (https://doi.org/10.1159/000332133)

Chan SY, Susarla R, Canovas D, Vasilopoulou E, Ohizua O, McCabe CJ, Hewison M \& Kilby MD 2015 Vitamin D promotes human extravillous trophoblast invasion in vitro. Placenta 36 403-409. (https://doi. org/10.1016/j.placenta.2014.12.021)

Chelstowska S, Widjaja-Adhi MAK, Silvaroli JA \& Golczak M 2016 Molecular basis for vitamin A uptake and storage in vertebrates. Nutrients 8 676. (https://doi.org/10.3390/nu8110676)

Chen Y-H, Yu Z, Fu L, Wang H, Chen X, Zhang C, Lv Z-M \& Xu D-X 2015 a Vitamin D3 inhibits lipopolysaccharide-induced placental inflammation through reinforcing interaction between vitamin $\mathrm{D}$ receptor and nuclear factor kappa B p65 subunit. Scientific Reports 5 10871. (https://doi. org/10.1038/srep10871)

Chen YH, Yu Z, Fu L, Xia MZ, Zhao M, Wang H, Zhang C, Hu YF, Tao FB \& Xu DX 2015b Supplementation with vitamin D3 during pregnancy protects against lipopolysaccharide-induced neural tube defects through improving placental folate transportation. Toxicological Sciences $\mathbf{1 4 5}$ 90-97. (https://doi.org/10.1093/toxsci/kfv036)

Chou JY 1982 Effects of retinoic acid on differentiation of choriocarcinoma cells in vitro. Journal of Clinical Endocrinology and Metabolism $\mathbf{5 4}$ 1174-1180. (https://doi.org/10.1210/jcem-54-6-1174)

Christensen KE, Hou W, Bahous RH, Deng L, Malysheva OV, Arning E, Bottiglieri T, Caudill MA, Jerome-Majewska LA \& Rozen R 2016 Moderate folic acid supplementation and MTHFD1-synthetase deficiency in mice, a model for the R653Q variant, result in embryonic defects and abnormal placental development, 2. American Journal of Clinical Nutrition 104 1459-1469. (https://doi.org/10.3945/ajcn.116.139519)

Clagett-Dame M \& Knutson D 2011 Vitamin A in reproduction and development. Nutrients 3 385-428. (https://doi.org/10.3390/nu3040385)

Cleal J, Day P, Simner C, Barton SJ, Mahon PA, Inskip H, Godfrey K, Hanson M, Cooper C \& Lewis RM 2015 Placental amino acid transport may be regulated by maternal vitamin $\mathrm{D}$ and vitamin D-binding protein: results from the Southampton Women's Survey. British Journal of Nutrition 113 1903-1910. (https://doi.org/10.1017/S0007114515001178)

Cordero AM, Crider KS, Rogers LM, Cannon MJ \& Berry RJ 2015 Optimal serum and red blood cell folate concentrations in women of reproductive age for prevention of neural tube defects: World Health Organization guidelines. Morbidity and Mortality Weekly Report 64 421-423.

Cox SE, Arthur P, Kirkwood BR, Yeboah-Antwi K \& Riley EM 2006 Vitamin A supplementation increases ratios of proinflammatory to antiinflammatory cytokine responses in pregnancy and lactation. Clinical and Experimental Immunology 144 392-400. (https://doi.org/10.1111/ j.1365-2249.2006.03082.x)

Cueto SM, Romney AD, Wang Y \& Walsh SW $1997 \beta$-Carotene attenuates peroxide-induced vasoconstriction in the human placenta. Journal of the Society for Gynecologic Investigation 4 64-71. (https://doi. org/10.1177/107155769700400203)

Darnton-Hill I \& Mkparu UC 2015 Micronutrients in pregnancy in lowand middle-income countries. Nutrients 7 1744-1768. (https://doi. org/10.3390/nu7031744)

de Benoist B 2008 Conclusions of a WHO Technical Consultation on folate and vitamin B12 deficiencies. Food and Nutrition Bulletin 29 S238S244. (https://doi.org/10.1177/15648265080292S129)

De-Regil LM, Peña-Rosas JP, Fernández-Gaxiola AC \& Rayco-Solon P 2015 Effects and safety of periconceptional oral folate supplementation for preventing birth defects. Cochrane Database of Systematic Reviews CD007950. (https://doi.org/10.1002/14651858.CD007950.pub3)

De-Regil LM, Palacios C, Lombardo LK \& Pena-Rosas JP 2016 Vitamin D supplementation for women during pregnancy. Cochrane Database of Systematic Reviews CD008873. (https://doi.org/10.1002/14651858. CD008873.pub2)

Di Simone N, Riccardi P, Maggiano N, Piacentani A, D'Asta M, Capelli A \& Caruso A 2004 Effect of folic acid on homocysteine-induced trophoblast apoptosis. Molecular Human Reproduction 10 665-669. (https://doi. org/10.1093/molehr/gah091)

Duggan C, Srinivasan K, Thomas T, Samuel T, Rajendran R, Muthayya S, Finkelstein JL, Lukose A, Fawzi W \& Allen LH 2014 Vitamin B-12 supplementation during pregnancy and early lactation increases maternal, breast milk, and infant measures of vitamin B-12 status, 2. Journal of Nutrition 144 758-764. (https://doi.org/10.3945/ jn.113.187278)

Dwarkanath P, Barzilay JR, Thomas T, Thomas A, Bhat S \& Kurpad AV 2013 High folate and low vitamin B-12 intakes during pregnancy are associated with small-for-gestational age infants in South Indian women: 
a prospective observational cohort study. American Journal of Clinical Nutrition 98 1450-1458. (https://doi.org/10.3945/ajcn.112.056382)

Ek J 1982 Plasma and red cell folate in mothers and infants in normal pregnancies: relation to birth weight. Acta Obstetricia et Gynecologica Scandinavica 61 17-20. (https://doi.org/10.3109/00016348209156944)

Evans KN, Bulmer JN, Kilby MD \& Hewison M 2004 Vitamin D and placental-decidual function. Journal of the Society for Gynecologic Investigation 11 263-271. (https://doi.org/10.1016/j.jsgi.2004.02.002)

Evans WJ, Morley JE, Argilés J, Bales C, Baracos V, Guttridge D, Jatoi A, Kalantar-Zadeh K, Lochs H \& Mantovani G 2008 Cachexia: a new definition. Clinical Nutrition 27 793-799. (https://doi.org/10.1016/j. clnu.2008.06.013)

Fan J, Ye J, Kamphorst JJ, Shlomi T, Thompson CB \& Rabinowitz JD 2014 Quantitative flux analysis reveals folate-dependent NADPH production. Nature 510 298-302. (https://doi.org/10.1038/nature13236)

FAO/WHO 2005 Vitamin and Mineral Requirements in Human Nutrition. World Health Organization and Food and Agriculture Organization of the United Nations, Geneva.

Fekete K, Berti C, Trovato M, Lohner S, Dullemeijer C, Souverein OW, Cetin I \& Decsi T 2012 Effect of folate intake on health outcomes in pregnancy: a systematic review and meta-analysis on birth weight, placental weight and length of gestation. Nutrition Journal 11 75. (https:// doi.org/10.1186/1475-2891-11-75)

Fisher AL \& Nemeth E 2017 Iron homeostasis during pregnancy. American Journal of Clinical Nutrition 106 1567S-1574S. (https://doi.org/10.3945/ ajcn.117.155812)

Friedrisch JR \& Friedrisch BK 2017 Prophylactic iron supplementation in pregnancy: a controversial issue. Biochemistry Insights 10 1178626417737738. (https://doi.org/10.1177/1178626417737738)

Gambling L, Charania Z, Hannah L, Antipatis C, Lea RG \& McArdle HJ 2002 Effect of iron deficiency on placental cytokine expression and fetal growth in the pregnant rat. Biology of Reproduction 66 516-523. (https://doi.org/10.1095/biolreprod66.2.516)

Gambling L, Czopek A, Andersen HS, Holtrop G, Srai SKS, Krejpcio Z \& McArdle HJ 2009 Fetal iron status regulates maternal iron metabolism during pregnancy in the rat. American Journal of Physiology: Regulatory, Integrative and Comparative Physiology 296 R1063-R1070. (https://doi. org/10.1152/ajpregu.90793.2008)

Ganguly A, Tamblyn JA, Finn-Sell S, Chan S-Y, Westwood M, Gupta J, Kilby MD, Gross SR \& Hewison M 2018Vitamin D, the placenta and early pregnancy: effects on trophoblast function. Journal of Endocrinology 236 R93-R103. (https://doi.org/10.1530/JOE-17-0491)

Gernand AD, Schulze KJ, Stewart CP, West KP Jr \& Christian P 2016 Micronutrient deficiencies in pregnancy worldwide: health effects and prevention. Nature Reviews Endocrinology 12 274. (https://doi. org/10.1038/nrendo.2016.37)

Girard S, Heazell AE, Derricott H, Allan SM, Sibley CP, Abrahams VM \& Jones RL 2014 Circulating cytokines and alarmins associated with placental inflammation in high-risk pregnancies. American Journal of Reproductive Immunology 72 422-434. (https://doi.org/10.1111/ aji.12274)

Guibourdenche J, Tarrade A, Laurendeau I, Rochette-Egly C, Chambon P, Vidaud M \& Evain-Brion D 2000 Retinoids stimulate leptin synthesis and secretion in human syncytiotrophoblast. Journal of Clinical Endocrinology and Metabolism 85 2550-2555. (https://doi.org/10.1210/ jcem.85.7.6695)

Gunshin H, Fujiwara Y, Custodio AO, DiRenzo C, Robine S \& Andrews NC 2005 Slc11a2 is required for intestinal iron absorption and erythropoiesis but dispensable in placenta and liver. Journal of Clinical Investigation 115 1258-1266. (https://doi.org/10.1172/JCI24356)

Gysler SM, Mulla MJ, Stuhlman M, Sfakianaki AK, Paidas MJ, Stanwood NL, Gariepy A, Brosens JJ, Chamley LW \& Abrahams VM 2015 Vitamin D reverses aPL-induced inflammation and LMWH-induced sFlt-1 release by human trophoblast. American Journal of Reproductive Immunology 73 242-250. (https://doi.org/10.1111/aji.12301)

Haberg SE, London SJ, Stigum H, Nafstad P \& Nystad W 2009 Folic acid supplements in pregnancy and early childhood respiratory health. Archives of Disease in Childhood 94 180-184. (https://doi.org/10.1136/ adc.2008.142448)

Haider BA, Olofin I, Wang M, Spiegelman D, Ezzati M \& Fawzi WW 2013 Anaemia, prenatal iron use, and risk of adverse pregnancy outcomes: systematic review and meta-analysis. BMJ 346 f3443. (https://doi. org/10.1136/bmj.f3443)

Hanson C, Lyden E, Abresch C \& Anderson-Berry A 2016 Serum retinol concentrations, race, and socioeconomic status in of women of childbearing age in the United States. Nutrients 8 508. (https://doi. org/10.3390/nu8080508)

Hay SM, McArdle HJ, Hayes HE, Stevens VJ \& Rees WD 2016 The effect of iron deficiency on the temporal changes in the expression of genes associated with fat metabolism in the pregnant rat. Physiological Reports 4 e12908. (https://doi.org/10.14814/phy2.12908)

Hodgetts V, Morris R, Francis A, Gardosi J \& Ismail K 2014 Effectiveness of folic acid supplementation in pregnancy on reducing the risk of smallfor-gestational age neonates: a population study, systematic review and meta-analysis. BJOG: An International Journal of Obstetrics and Gynaecology 122 478-490. (https://doi.org/10.1111/1471-0528.13202)

Hollingsworth JW, Maruoka S, Boon K, Garantziotis S, Li Z, Tomfohr J, Bailey N, Potts EN, Whitehead G, Brass DM et al. 2008 In utero supplementation with methyl donors enhances allergic airway disease in mice. Journal of Clinical Investigation 118 3462-3469. (https://doi. org/10.1172/JCl87742)

Houghton LA \& Vieth R 2006 The case against ergocalciferol (vitamin D2) as a vitamin supplement1,2. American Journal of Clinical Nutrition 84 694-697. (https://doi.org/10.1093/ajcn/84.4.694)

Jiang B, Zhang Z, Zheng P, Ju L, Tang K \& Lou Y 2014 Apoptotic genes expression in placenta of clubfoot-like fetus pregnant rats. International Journal of Clinical and Experimental Pathology 7677.

Kato Y \& Braunstein GD 1991 Retinoic acid stimulates placental hormone secretion by choriocarcinoma cell lines in vitro. Endocrinology 128 401-407. (https://doi.org/10.1210/endo-128-1-401)

Kell DB \& Kenny LC 2016 A dormant microbial component in the development of preeclampsia. Frontiers in Medicine 3 60. (https://doi. org/10.3389/fmed.2016.00060)

Khot V, Kale A, Joshi A, Chavan-Gautam P \& Joshi S 2014 Expression of genes encoding enzymes involved in the one carbon cycle in rat placenta is determined by maternal micronutrients (folic acid, vitamin B12) and omega-3 fatty acids. BioMed Research International 2014 613078. (https://doi.org/10.1155/2014/613078)

Kim J-M, Hong K, Lee JH, Lee S \& Chang N 2009 Effect of folate deficiency on placental DNA methylation in hyperhomocysteinemic rats. Journal of Nutritional Biochemistry 20 172-176. (https://doi.org/10.1016/j. jnutbio.2008.01.010)

Kovacs CS, Woodland ML, Fudge NJ \& Friel JK 2005 The vitamin D receptor is not required for fetal mineral homeostasis or for the regulation of placental calcium transfer in mice. American Journal of Physiology: Endocrinology and Metabolism 289 E133-E144. (https://doi. org/10.1152/ajpendo.00354.2004)

Kulkarni A, Dangat K, Kale A, Sable P, Chavan-Gautam P \& Joshi S 2011 Effects of altered maternal folic acid, vitamin B12 and docosahexaenoic acid on placental global DNA methylation patterns in Wistar rats. PLOS ONE 6 e17706. (https://doi.org/10.1371/journal.pone.0017706)

Lassi ZS, Salam RA, Haider BA \& Bhutta ZA 2013 Folic acid supplementation during pregnancy for maternal health and pregnancy outcomes. Cochrane Database of Systematic Reviews CD006896. (https://doi.org/10.1002/14651858.CD006896.pub2)

Lewis R, Doherty C, James L, Burton G \& Hales C 2001 Effects of maternal iron restriction on placental vascularization in the rat. Placenta 22 534-539. (https://doi.org/10.1053/plac.2001.0679)

Liu NQ, Kaplan AT, Lagishetty V, Ouyang YB, Ouyang Y, Simmons CF, Equils O \& Hewison M 2011 Vitamin D and the regulation of placental inflammation. Journal of Immunology 186 5968-5974. (https://doi. org/10.4049/jimmunol.1003332)

Liu NQ, Larner DP, Yao Q, Chun RF, Ouyang Y, Zhou R, Tamblyn JA, Wagner CL \& Hewison M 2017 Vitamin D-deficiency and sex-specific dysregulation of placental inflammation. Journal of Steroid Biochemistry and Molecular Biology $177 \quad 223-230 . \quad$ (https://doi.org/10.1016/j. jsbmb.2017.06.012)

Liu NQ, Ouyang Y, Bulut Y, Lagishetty V, Chan SY, Hollis BW, Wagner C, Equils O \& Hewison M 2013 Dietary vitamin D restriction in pregnant female mice is associated with maternal hypertension and altered placental and fetal development. Endocrinology 154 2270-2280. (https://doi.org/10.1210/en.2012-2270) 
Looker AC, Pfeiffer CM, Lacher DA, Schleicher RL, Picciano MF \& Yetley EA 2008 Serum 25-hydroxyvitamin D status of the US population: 1988-1994 compared with 2000-2004. American Journal of Clinical Nutrition 88 1519-1527. (https://doi.org/10.3945/ajcn.2008.26182)

Lopez-Diaz F, Nores R, Panzetta-Dutari G, Slavin D, Prieto C, Koritschoner N \& Bocco J 2007 RXR $\alpha$ regulates the pregnancy-specific glycoprotein 5 gene transcription through a functional retinoic acid responsive element. Placenta 28 898-906. (https://doi.org/10.1016/j. placenta.2007.03.002)

Love A \& Vickers T 1976 Placental agenesis, embryonal hydraemia, embryolethality and acute hypervitaminosis A in rats. British Journal of Experimental Pathology $\mathbf{5 7} 525$.

Lu X-J, Deb S \& Soares MJ 1994 Spontaneous differentiation of trophoblast cells along the spongiotrophoblast cell pathway: expression of members of the placental prolactin gene family and modulation by retinoic acid. Developmental Biology 163 86-97. (https://doi.org/10.1006/ dbio.1994.1125)

Ma S-L, Tian X-Y, Wang Y-Q, Zhang H-F \& Zhang L 2017 Vitamin D supplementation prevents placental ischemia induced endothelial dysfunction by downregulating placental soluble FMS-Like tyrosine kinase-1. DNA and Cell Biology 36 1134-1141. (https://doi.org/10.1089/ dna.2017.3817)

Malek A 2010 In vitro studies of ferric carboxymaltose on placental permeability using the dual perfusion model of human placenta. Arzneimittelforschung $\quad 60 \quad 354-361 . \quad$ (https://doi. org/10.1055/s-0031-1296300)

Mark M, Ghyselinck NB \& Chambon P 2009 Function of retinoic acid receptors during embryonic development. Nuclear Receptor Signaling 7 e002. (https://doi.org/10.1621/nrs.07002)

McArdle HJ, Gambling L \& Kennedy C 2014 Iron deficiency during pregnancy: the consequences for placental function and fetal outcome. Proceedings of the Nutrition Society 73 9-15. (https://doi.org/10.1017/ S0029665113003637)

McCauley ME, van den Broek N, Dou L \& Othman M 2015 Vitamin A supplementation during pregnancy for maternal and newborn outcomes. Cochrane Database of Systematic Reviews CD008666. (https://doi. org/10.1002/14651858.CD008666.pub3)

McKay JA \& Mathers JC 2016 Maternal folate deficiency and metabolic dysfunction in offspring. Proceedings of the Nutrition Society 75 90-95. (https://doi.org/10.1017/S0029665115004280)

Mikael LG, Pancer J, Jiang X, Wu Q, Caudill M \& Rozen R 2013 Low dietary folate and methylenetetrahydrofolate reductase deficiency may lead to pregnancy complications through modulation of ApoAl and IFN- $\gamma$ in spleen and placenta, and through reduction of methylation potential. Molecular Nutrition and Food Research 57 661-670. (https:// doi.org/10.1002/mnfr.201200152)

Molloy AM 2012 Genetic aspects of folate metabolism. $\begin{array}{lllll}\text { Subcellular Biochemistry } & \mathbf{5 6} & 105-130 . & \text { (https://doio }\end{array}$ rg/10.1007/978-94-007-2199-9_7)

Moussa C, Ross N, Jolette P \& MacFarlane AJ 2015 Altered folate metabolism modifies cell proliferation and progesterone secretion in human placental choriocarcinoma JEG-3 cells. British Journal of Nutrition 114 844-852. (https://doi.org/10.1017/S0007114515002688)

Nadeau-Vallee M, Obari D, Palacios J, Brien ME, Duval C, Chemtob S \& Girard S 2016 Sterile inflammation and pregnancy complications: a review. Reproduction 152 R277-R292. (https://doi.org/10.1530/REP-160453)

Nebel L \& Ornoy A 1971 Structural alterations in rat placenta following hypervitaminosis D2. Israel Journal of Medical Sciences 7 647-655.

Nebel L \& Ornoy A 1972 Interdependence of fetal anomalies and placental impairment following maternal hypervitaminosis $\mathrm{D}$ and hypercortisonism. In Drugs and Fetal Development, pp 251-255. Springer, Boston, MA. (https://doi.org/10.1007/978-1-4684-3219-0_20)

Nelson MM, Asling CW \& Evans HM 1952 Production of multiple congenital abnormalities in young by maternal pteroylglutamic acid deficiency during gestation. Journal of Nutrition 48 61-79. (https://doi. org/10.1093/jn/48.1.61)

Nguyen T, Yong H, Chollangi T, Borg A, Brennecke S \& Murthi P 2015 Placental vitamin D receptor expression is decreased in human idiopathic fetal growth restriction. Journal of Molecular Medicine 93 795-805. (https://doi.org/10.1007/s00109-015-1267-1)
Noyola-Martinez N, Diaz L, Avila E, Halhali A, Larrea F \& Barrera D 2013 Calcitriol downregulates TNF-alpha and IL-6 expression in cultured placental cells from preeclamptic women. Cytokine 61 245-250. (https://doi.org/10.1016/j.cyto.2012.10.001)

Olmos-Ortiz A, Noyola-Martinez N, Barrera D, Zaga-Clavellina V, Avila E, Halhali A, Biruete B, Larrea F \& Diaz L 2015 IL-10 inhibits while calcitriol reestablishes placental antimicrobial peptides gene expression. Journal of Steroid Biochemistry and Molecular Biology 148 187-193. (https://doi.org/10.1016/j.jsbmb.2014.07.012)

Ornoy O, Menczel J \& Nebel L 1968 Alterations in the mineral composition and metabolism of rat fetuses and their placentas induced by maternal hypervitaminosis D2. Israel Journal of Medical Sciences 4 827-832.

Penailillo R, Guajardo A, Llanos M, Hirsch S \& Ronco AM 2015 Folic acid supplementation during pregnancy induces sex-specific changes in methylation and expression of placental 11ß-hydroxysteroid dehydrogenase 2 in rats. PLOS ONE 10 e0121098. (https://doi. org/10.1371/journal.pone.0121098)

Pickell L, Li D, Brown K, Mikael LG, Wang XL, Wu Q, Luo L, JeromeMajewska L \& Rozen R 2009 Methylenetetrahydrofolate reductase deficiency and low dietary folate increase embryonic delay and placental abnormalities in mice. Birth Defects Research Part A: Clinical and Molecular Teratology 85 531-541. (https://doi.org/10.1002/bdra.20575)

Pickell L, Brown K, Li D, Wang XL, Deng L, Wu Q, Selhub J, Luo L, Jerome-Majewska L \& Rozen R 2011 High intake of folic acid disrupts embryonic development in mice. Birth Defects Research Part A: Clinical and Molecular Teratology 91 8-19. (https://doi.org/10.1002/bdra.20754)

Potvliege P 1962 Hypervitaminosis D2 in gravid rats: study of its influence on fetal parathyroid glands and a report of hitherto undescribed placental alterations. Archives of Pathology 73 371-382.

Radhika M, Bhaskaram P, Balakrishna N, Ramalakshmi B, Devi S \& Kumar BS 2002 Effects of vitamin A deficiency during pregnancy on maternal and child health. BJOG: An International Journal of Obstetrics and Gynaecology 109 689-693. (https://doi.org/10.1111/j.14710528.2002.01010.x)

Rao S, Yajnik CS, Kanade A, Fall CH, Margetts BM, Jackson AA, Shier R, Joshi S, Rege S \& Lubree H 2001 Intake of micronutrient-rich foods in rural Indian mothers is associated with the size of their babies at birth: Pune Maternal Nutrition Study. Journal of Nutrition 131 1217-1224. (https://doi.org/10.1093/jn/131.4.1217)

Rogne T, Tielemans MJ, Chong MF-F, Yajnik CS, Krishnaveni GV, Poston L, Jaddoe VW, Steegers EA, Joshi S \& Chong Y-S 2017 Associations of maternal vitamin B12 concentration in pregnancy with the risks of preterm birth and low birth weight: a systematic review and metaanalysis of individual participant data. American Journal of Epidemiology 185 212-223. (https://doi.org/10.1093/aje/kww212)

Rosario FJ, Powell TL \& Jansson T 2017a mTOR folate sensing links folate availability to trophoblast cell function. Journal of Physiology $\mathbf{5 9 5}$ 4189-4206. (https://doi.org/10.1113/JP272424)

Rosario JF Nathanielsz PW Powell TL Jansson T 2017 b Maternal folate deficiency causes inhibition of mTOR signaling, downregulation of placental amino acid transporters and fetal growth restriction in mice. Scientific Reports 7 3982. (https://doi.org/10.1038/s41598-01703888-2)

Ross AC 2017 Impact of chronic and acute inflammation on extra-and intracellular iron homeostasis. American Journal of Clinical Nutrition 106 1581S-1587S. (https://doi.org/10.3945/ajcn.117.155838)

Roth DE, Leung M, Mesfin E, Qamar H, Watterworth J \& Papp E 2017 Vitamin D supplementation during pregnancy: state of the evidence from a systematic review of randomised trials. BMJ 359 j5237. (https:// doi.org/10.1136/bmj.j5237)

Ryan JW, Anderson PH \& Morris HA 2015 Pleiotropic activities of vitamin $\mathrm{D}$ receptors-adequate activation for multiple health outcomes. Clinical Biochemist Reviews 3653.

Scholl TO 2005 Iron status during pregnancy: setting the stage for mother and infant. American Journal of Clinical Nutrition 81 1218S-1222S. (https://doi.org/10.1093/ajcn/81.5.1218)

Scholl TO \& Johnson WG 2000 Folic acid: influence on the outcome of pregnancy. American Journal of Clinical Nutrition 71 1295S-1303S. (https://doi.org/10.1093/ajcn/71.5.1295s)

Shah T, Joshi K, Mishra S, Otiv S \& Kumbar V 2016 Molecular and cellular effects of vitamin B12 forms on human trophoblast cells in presence 
of excessive folate. Biomedicine and Pharmacotherapy 84 526-534. (https://doi.org/10.1016/j.biopha.2016.09.071)

Shah T, Mishra S, More A, Otiv S, Apte K \& Joshi K 2017 Combination of vitamin B12 active forms improved fetal growth in Wistar rats through up-regulation of placental miR-16 and miR-21 levels. Life Sciences 191 97-103. (https://doi.org/10.1016/j.Ifs.2017.10.017)

Shaker O \& Sadik N 2013 Pathogenesis of preeclampsia: implications of apoptotic markers and oxidative stress. Human and Experimental Toxicology 32 1170-1178. (https://doi.org/10.1177/0960327112472998)

Sherman AR \& Moran PE 1984 Copper metabolism in iron-deficient maternal and neonatal rats. Journal of Nutrition 114 298-306. (https:// doi.org/10.1093/jn/114.2.298)

Shin JS, Choi MY, Longtine MS \& Nelson DM 2010 Vitamin D effects on pregnancy and the placenta. Placenta 31 1027-1034. (https://doi. org/10.1016/j.placenta.2010.08.015)

Solanky N, Jimenez AR, D'Souza S, Sibley C \& Glazier J 2010 Expression of folate transporters in human placenta and implications for homocysteine metabolism. Placenta 31 134-143. (https://doi.org/10.1016/j. placenta.2009.11.017)

Spiegler E, Kim Y-K, Wassef L, Shete V \& Quadro L 2012 Maternal-fetal transfer and metabolism of vitamin $\mathrm{A}$ and its precursor $\beta$-carotene in the developing tissues. Biochimica et Biophysica Acta (BBA): Molecular and Cell Biology of Lipids 1821 88-98. (https://doi.org/10.1016/j. bbalip.2011.05.003)

Srigiridhar K \& Nair KM 2000 Supplementation with $\alpha$-tocopherol or a combination of $\alpha$-tocopherol and ascorbic acid protects the gastrointestinal tract of iron-deficient rats against iron-induced oxidative damage during iron repletion. British Journal of Nutrition $\mathbf{8 4}$ 165-173.(https://doi.org/10.1017/S0007114500001392)

Srigiridhar K, Nair KM, Subramanian R \& Singotamu L 2001 Oral repletion of iron induces free radical mediated alterations in the gastrointestinal tract of rat. Molecular and Cellular Biochemistry 219 91-98. (https://doi. org/10.1023/A:1011023111048)

Steegers-Theunissen RP, Smith SC, Steegers EA, Guilbert LJ \& Baker PN 2000 Folate affects apoptosis in human trophoblastic cells. BJOG $\mathbf{1 0 7}$ 1513-1515. (https://doi.org/10.1111/j.1471-0528.2000.tb11677.x)

Stephanou A, Ross R \& Handwerger S 1994 Regulation of human placental lactogen expression by 1, 25-dihydroxyvitamin D3. Endocrinology 135 2651-2656. (https://doi.org/10.1210/endo.135.6.7988455)

Suh JR, Herbig AK \& Stover PJ 2001 New perspectives on folate catabolism. Annual Review of Nutrition 21 255-282. (https://doi.org/10.1146/ annurev.nutr.21.1.255)

Sukumar N, Rafnsson SB, Kandala N-B, Bhopal R, Yajnik CS \& Saravanan P 2016 Prevalence of vitamin B-12 insufficiency during pregnancy and its effect on offspring birth weight: a systematic review and meta-analysis. American Journal of Clinical Nutrition 103 1232-1251. (https://doi. org/10.3945/ajcn.115.123083)

Swali A, McMullen S, Hayes H, Gambling L, McArdle HJ \& LangleyEvans SC 2011 Cell cycle regulation and cytoskeletal remodelling are critical processes in the nutritional programming of embryonic development. PLOS ONE 6 e23189. (https://doi.org/10.1371/journal. pone.0023189)

Takahashi YI, Smith JE, Winick M \& Goodman DS 1975 Vitamin A deficiency and fetal growth and development in the rat. Journal of Nutrition 105 1299-1310. (https://doi.org/10.1093/jn/105.10.1299)

Tamblyn JA, Hewison M, Wagner CL, Bulmer JN \& Kilby MD 2015 Immunological role of vitamin D at the maternal-fetal interface. Journal of Endocrinology 224 R107-R121. (https://doi.org/10.1530/JOE-14-0642)

Tamblyn J, Susarla R, Jenkinson C, Jeffery L, Ohizua O, Chun R, Chan S, Kilby M \& Hewison M 2017 Dysregulation of maternal and placental vitamin D metabolism in preeclampsia. Placenta 50 70-77. (https://doi. org/10.1016/j.placenta.2016.12.019)

Tarrade A, Schoonjans K, Pavan L, Auwerx J, Rochette-Egly Cc, EvainBrion DI \& Fournier T 2001 PPAR $\gamma / R X R \alpha$ heterodimers control human trophoblast invasion. Journal of Clinical Endocrinology and Metabolism 86 5017-5024. (https://doi.org/10.1210/jcem.86.10.7924)

Tesic D, Hawes JE, Zosky GR \& Wyrwoll CS 2015 Vitamin D deficiency in $\mathrm{BALB} / \mathrm{C}$ mouse pregnancy increases placental transfer of glucocorticoids. Endocrinology 156 3673-3679. (https://doi.org/10.1210/en.2015-1377)

Tian X, Ma S, Wang Y, Hou L, Shi Y, Yao M, Wang X, Zhang H \& Jiang L 2016 Effects of placental ischemia are attenuated by 1,25 -dihydroxyvitamin $\mathrm{D}$ treatment and associated with reduced apoptosis and increased autophagy. DNA and Cell Biology 35 59-70. (https://doi.org/10.1089/ dna.2015.2885)

Toblli J, Cao G, Oliveri L \& Angerosa M 2012 Effects of iron deficiency anemia and its treatment with iron polymaltose complex in pregnant rats, their fetuses and placentas: oxidative stress markers and pregnancy outcome. Placenta 33 81-87. (https://doi.org/10.1016/j. placenta.2011.11.017)

Toblli JE, Cao G, Oliveri L \& Angerosa M 2013 Effects of iron polymaltose complex, ferrous fumarate and ferrous sulfate treatments in anemic pregnant rats, their fetuses and placentas. Inflammation and AllergyDrug Targets 12 190-198. (https://doi.org/10.2174/187152811131299 90040)

Tojyo H 1983 Effect of different intensities of iron-deficient anemia in pregnant rats on maternal tissue iron and fetal development. Journal of Nutritional Science and Vitaminology 29 339-351. (https://doi. org/10.3177/jnsv.29.339)

Torheim LE, Ferguson EL, Penrose K \& Arimond M 2010 Women in resource-poor settings are at risk of inadequate intakes of multiple micronutrients. Journal of Nutrition 140 2051S-2058S. (https://doi. org/10.3945/jn.110.123463)

Tuan RS, Moore CJ, Brittingham JW, Kirwin JJ, Akins RE \& Wong M 1991 In vitro study of placental trophoblast calcium uptake using JEG-3 human choriocarcinoma cells. Journal of Cell Science 98 333-342.

van Uitert EM \& Steegers-Theunissen RP 2012 Influence of maternal folate status on human fetal growth parameters. Molecular Nutrition and Food Research 57 582-595. (https://doi.org/10.1002/mnfr.201200084)

Villamor E \& Fawzi WW 2005 Effects of vitamin a supplementation on immune responses and correlation with clinical outcomes. Clinical Microbiology Reviews 18 446-464. (https://doi.org/10.1128/ CMR.18.3.446-464.2005)

Wadhwani NS, Dangat KD, Joshi AA \& Joshi SR 2013 Maternal micronutrients and omega 3 fatty acids affect placental fatty acid desaturases and transport proteins in Wistar rats. Prostaglandins, Leukotrienes and Essential Fatty Acids 88 235-242. (https://doi. org/10.1016/j.plefa.2012.12.002)

Walter PB, Knutson MD, Paler-Martinez A, Lee S, Xu Y, Viteri FE \& Ames BN 2002 Iron deficiency and iron excess damage mitochondria and mitochondrial DNA in rats. PNAS 99 2264-2269. (https://doi. org/10.1073/pnas.261708798)

Wang LQ, Yan XT, Yan CF, Zhang XW, Hui LY, Xue M \& Yu XW 2016 Women with raecurrent miscarriage have decreased expression of 25-hydroxyvitamin D3-1alpha-hydroxylase by the fetal-maternal interface. PLOS ONE 11 e0165589. (https://doi.org/10.1371/journal. pone.0165589)

Wei SQ, Qi HP, Luo ZC \& Fraser WD 2013 Maternal vitamin D status and adverse pregnancy outcomes: a systematic review and meta-analysis. Journal of Maternal-Fetal and Neonatal Medicine 26 889-899. (https:// doi.org/10.3109/14767058.2013.765849)

Wellik DM \& Deluca HF 1995 Retinol in addition to retinoic acid is required for successful gestation in vitamin A-deficient rats. Biology of Reproduction 53 1392-1397. (https://doi.org/10.1095/ biolreprod53.6.1392)

Wendling O, Chambon P \& Mark M 1999 Retinoid X receptors are essential for early mouse development and placentogenesis. PNAS 96 547-551. (https://doi.org/10.1073/pnas.96.2.547)

White JC, Shankar VN, Highland M, Epstein ML, DeLuca HF \& ClagettDame M 1998 Defects in embryonic hindbrain development and fetal resorption resulting from vitamin A deficiency in the rat are prevented by feeding pharmacological levels of all-trans-retinoic acid. PNAS 95 13459-13464. (https://doi.org/10.1073/pnas.95.23.13459)

Whitrow MJ, Moore VM, Rumbold AR \& Davies MJ 2009 Effect of supplemental folic acid in pregnancy on childhood asthma: a prospective birth cohort study. American Journal of Epidemiology 170 1486-1493. (https://doi.org/10.1093/aje/kwp315)

Wilson RL, Buckberry S, Spronk F, Laurence JA, Leemaqz S, O'Leary S, Bianco-Miotto T, Du J, Anderson PH \& Roberts CT 2015 Vitamin D receptor gene ablation in the conceptus has limited effects on placental morphology, function and pregnancy outcome. PLOS ONE 10 e0131287. (https://doi.org/10.1371/journal.pone.0131287)

Wiseman EM, Bar-El Dadon S \& Reifen R 2017 The vicious cycle of vitamin A deficiency: a review. Critical Reviews in Food Science and Nutrition $\mathbf{5 7}$ 3703-3714. (https://doi.org/10.1080/10408398.2016.1160362) 
Woodman AG, Care AS, Mansour Y, Cherak SJ, Panahi S, Gragasin FS \& Bourque SL 2017 Modest and severe maternal iron deficiency in pregnancy are associated with fetal anaemia and organ-specific hypoxia in rats. Scientific Reports 7 46573. (https://doi.org/10.1038/srep46573)

World Health Organization 2009 Global Prevalence of Vitamin A Deficiency in Populations at Risk 1995-2005: WHO Global Database on Vitamin A Deficiency.

Worton S, Sibley C \& Heazell A 2014 Understanding the placental aetiology of fetal growth restriction; could this lead to personalized management strategies? Fetal and Maternal Medicine Review 25 95-116. (https://doi. org/10.1017/S0965539514000114)

Xu J, Jia X, Gu Y, Lewis DF, Gu X \& Wang Y 2017 Vitamin D reduces oxidative stress-induced procaspase-3/ROCK1 activation and MP release by placental trophoblasts. Journal of Clinical Endocrinology and Metabolism 102 2100-2110. (https://doi.org/10.1210/jc.2016-3753)

Received 12 March 2018

First decision 27 April 2018

Revised manuscript received 15 May 2018

Accepted 29 May 2018 